fournal of Medical Genetics (1975). 12, 12.

\title{
A genetic study of torsion dystonia
}

\author{
SARAH BUNDEY,* M. J. G. HARRISON, $\dagger$ and C. D. MARSDEN $\ddagger$
}

\begin{abstract}
Summary. A family study of 32 patients with torsion dystonia has shown at least two forms of generalized dystonia with onset in childhood. These two forms, an autosomal dominant and an autosomal recessive, are clinically indistinguishable. There were at least three families and probably about six to eight patients with the autosomal recessive variety. The remaining nine to 11 patients with generalized childhood dystonia are thought, because of a probable paternal age effect, to be examples of new dominant mutations. Since fitness with childhood onset is $1 / 20$ of normal, most childhood dominant cases appear sporadically. Most of the other 15 patients (12 with onset in adult life) appear to have a non-genetic torsion dystonia, although an example of a benign adult-onset dominant form associated with a tremor has been observed.

It is concluded that there are at least two forms of genetic torsion dystonia, an autosomal recessive form with onset in childhood, which, on evidence from America, is particularly common in Ashkenazi Jews, and one or more dominant forms, with onset in childhood or adult life. The majority of adult-onset isolated cases of idiopathic torsion dystonia seem to be due to exogenous but unidentified causes.
\end{abstract}

Torsion dystonia is sometimes used as a descriptive term for abnormal dystonic movements whatever the cause. In this paper however the term is reserved for a condition without obvious cause, and without other neurological abnormalities. Torsion dystonia is defined here as an idiopathic progressive disorder, characterized by dystonic movements and postures. The rate of progression is variable, but Herz (1944) and Marsden and Harrison (1974) have pointed out that the prognosis is related to the age of onset, and to the mode of presentation, so that severer disease follows onset in childhood with dystonia of a leg, and milder disease follows onset in adult life with dystonia of the arms or trunk. It has been observed since the early 20th century that a severe form with onset in childhood

\section{Received 17 June 1974.}

* MRC Clinical Genetics Unit, Institute of Child Health, London WC1N 1EH and Institute of Neurology, Queen Square, London. Present address: The Infant Develomment Unit, Queen Elizabeth Medical Centre, Birmingham, B15 2TG.

† The National Hospitals for Nervous Diseases, Queen Square, London WC1N 1EH. Present address: The Middlesex Hospital, Mortimer Street, London W1.

₹ University Department of Neurology, Institute of Psychiatry and Kings College Hospital, De Crespigny Park, London SE5. is commoner in Jews from Russia and Poland (for a review see Eldridge, 1970).

Idiopathic torsion dystonia may occur in families, and patterns consistent with both autosomal dominant and autosomal recessive modes of inheritance have been reported. Dominant torsion dystonia has been described by Zeman et al (1959), Johnson, Schwartz, and Barbeau (1962), and Yanagisawa, Goto, and Narabayashi (1972). A feature of these familial dominant cases was a variable clinical picture, ranging from onset in childhood and severe disability, to onset in adult life and only mild affection. Torticollis, dystonia of spinal musculature, tremor and blepharospasm were frequent manifestations, in addition to dystonia of limbs. The affected individuals in the large Swedish pedigree with dominant inheritance described by Larsson and Sjögren (1966) had a distinctive form of torsion dystonia, where tremor was prominent, and where axial rigidity developed in about half the cases.

The conclusion of Zeman and Dyken (1968) that all cases of idiopathic torsion dystonia are due to an autosomal dominant gene is untenable in view of the families reported with sibs but no parent affected, and in view of the high incidence in Ashkenazi Jews 
(Eldridge, 1970). In this American study, Eldridge showed that there was a higher frequency of torsion dystonia in New York compared to the rest of the United States, and that this was due to a large proportion of Jewish cases. He studied 96 families in detail; 41 of these were Jewish. In seven or eight of the Jewish families the distribution of secondary cases was consistent with autosomal recessive inheritance, and it was likely that an increased frequency of the recessive gene for torsion dystonia accounted for the increased incidence of the disease in Jews. Eldrige, Edgar, and Cooper (1971) estimated the carrier frequency in the American Ashkenazim to be 1 in 100 . However, the incidence of torsion dystonia in sibs of Jewish patients, with 'typical' dystonia and without an affected parent, was only 5 out of 53 , which is too low for the 1 in 4 incidence expected if autosomal recessive inheritance accounted for all Jewish cases. There were also both Jewish and non Jewish families in his study where torsion dystonia appeared in parent and child. Unfortunately the study was biased for familial cases and so the relative frequency of recessive and dominant torsion dystonia in Jews and in non Jews could not be assessed.

The contribution of dominant and recessive torsion dystonia to the total incidence of cases has not yet been established. From series of hospital patients with torsion dystonia, it is clear that most cases have no affected relative (Herz, 1944; Eldridge, 1970). Zeman et al (1959) and Zeman and Dyken (1967) suggested that these isolated cases are either examples of new dominant mutations, or that disease in their relatives has been mild and unrecognized.

The present study was planned with the aims of determining what proportion of cases of idiopathic torsion dystonia was genetic, of assessing the relative frequencies of the autosomal dominant and recessive forms, and of obtaining empirical risks of recurrence for genetic counselling.

\section{Methods}

The following criteria for the inclusion of patients were used. (1) An illness characterized by the gradual development of dystonic movements and postures. excluding patients with spasmodic torticollis only. (2) No history of perinatal hypoxia or jaundice, and no exposure to drugs before the appearance of first signs. (3) No sensory symptoms, and no pyramidal, cerebellar, or sensory signs. No intellectual deterioration. (4) No cause for the dystonia found on investigations, which always included studies of copper metabolism.

The names of patients with torsion dystonia were obtained from the National Hospitals (at Queen Square and
Maida Vale) where the diagnostic index went back to 1956; from The Hospital for Sick Children, Great Ormond Street, whose index went back to 1954, and more recent records of the Neurology Departments of the Maudsley Hospital and King's College Hospital. In addition all doctors responsible for patients in residential care, and all Medical Officers of Health in the Metropolitan Areas were asked if they knew of cases of torsion dystonia. Twenty-nine patients whose names were obtained were subsequently excluded as they did not meet the criteria given above, and were considered to be examples of symptomatic torsion dystonia. There were 53 patients who fitted the criteria given above and clinical findings of 42 of these were described by Marsden and Harrison (1974). Of the total of 53, 21 were unavailable for the genetic study; 11 had moved abroad or to distant parts of Great Britain; four had died; two could not be traced, and permission to visit four patients was refused. There were then 32 index patients in the genetic study; of these, 31 had been ascertained through hospital records and only one (case 16) through the Metropolitan Survey.

All 32 patients were visited at home and reassessed clinically. A family history was taken from the patient and supplemented where possible by interview with a parent. Questions were asked about the following disorders in relatives: torticollis, abnormal movements, writer's cramp, or a limp. Any relative with a reported disorder of movement was seen, or medical information obtained from his or her hospital consultant. In addition, all available first-degree relatives were examined for evidence of abnormal movements, or abnormal posturing, occurring spontaneously or brought out by activities such as writing, walking, or by specific tests of coordination. Where possible photographs of dead parents and grandparents were inspected.

The 32 index patients had a total of 169 first-degree relatives. Of these, 96 were examined: 37 parents, 38 sibs, and 21 children. Reasons for not seeing the remaining 73 relatives were as follows: dead (28); lived too far away for a visit (19); address was unknown (18); refused a visit (8). The ascertainment of the index patients and their relatives is shown in Table I.

Methods for comparing parental ages. The observed ages of parents of patients are given below but we describe here the population data used for their comparison. Parents' ages at times of birth of their children depend partly on social trends (as indicated by differences in mean maternal ages in different years, and in different populations); partly on numbers of previous children; and, in older ages, on the age of spouses. For making comparisons we have used the population data for England and Wales, provided by the Registrar General, taking these three factors into account.

The Registrar General gives tables from 1938 onwards where the maternal age at the birth of a child is given, and is also related to number of previous children. For years before 1938 the Registrar General has constructed age fertility tables, based on the observed age fertility 
TABLE I ASCERTAINMENT OF THE 32 INDEX PATIENTS AND THEIR FIRST-DEGREE RELATIVES

\begin{tabular}{l|c|c|c|c|c|c|c|c}
\hline & Total & Dead & Too Far Away & Address Unknown & Refused & Seen \\
\hline Index patients & 53 & 4 & 11 & 2 & 4 & 32 \\
Parents & 64 & 18 & 4 & 2 & 37 \\
Full liveborn sibs & 78 & 9 & 11 & 16 & 4 & 38 \\
Children & 27 & 1 & 4 & 0 & 1 & 21 \\
\hline
\end{tabular}

rates in 1938, and the observed age distributions of women in earlier years. From these constructed age fertility tables one can obtain estimates of mean maternal age for individual years before 1938, but these are not adjusted for parity.

Data on paternal age are only provided from 1962 onwards, but before this the Registrar General provided tables of husbands' and wives' ages at times of marriage. Penrose in 1955 pointed out that differences in husbands' and wives' ages could separate a paternal age effect from a maternal one, and so the value of these tables was assessed by Bundey and Evans (1969). These workers showed firstly, that there has been little change in the husband-wife age differences over the last 50 years, in spite of lowering of mean age at marriage, and mean age at maternity. Second, they showed that the husbandwife age difference varies at different wifely ages; and third, that the husband-wife age difference is a good indication of father-mother age difference until the wifely age of 40 years. After this wifely age the husbands who become fathers are younger than those who do not. For example, the mean age of husbands marrying women aged 40-49 years between 1962 and 1966 was 3.5 years above the mean age of husbands, with wives aged 40-49 who had children between 1962 and 1966. Before the wifely age of 40 years it is reasonable to use the husbandwife age difference as an indication of father-mother age difference, but after the wifely age of 40 , it is more appropriate to use the observed father-mother age differences available from 1962. In Table II we give these differences for different wifely ages. This Table has been used to obtain estimates of paternal ages (given in Table III) based on the population data for maternal ages.

TABLE II

MEAN DIFFERENCES IN AGES BETWEEN SPOUSES (From the Registrar General's Tables 1921-66)

\begin{tabular}{c|c}
\hline Age Group of Wives (years) & Husband's Age-Wife's Age (years) \\
$1921-53$
\end{tabular}

TABLE III

PARENTAL AGES OF ISOLATED CASES OF TORSION DYSTONIA (GROUP A) COMPARED WITH PARENTAL AGES IN THE POPULATION

\begin{tabular}{|c|c|c|c|c|c|c|}
\hline $\begin{array}{l}\text { Year of Birth } \\
\text { of Patient }\end{array}$ & $\begin{array}{c}\text { Observed } \\
\text { Maternal Age }\end{array}$ & $\begin{array}{c}\text { Expected* } \\
\text { Maternal Age }\end{array}$ & $\begin{array}{c}\text { Observed } \\
\text { Paternal Age }\end{array}$ & $\begin{array}{c}\text { Expectedt } \\
\text { Paternal Age }\end{array}$ & $\begin{array}{c}\text { Observed } \\
\text { Paternal-Maternal } \\
\text { Age Difference }\end{array}$ & $\begin{array}{c}\text { Expected } \ddagger \\
\text { Paternal-Maternal } \\
\text { Age Difference }\end{array}$ \\
\hline $\begin{array}{l}1921 \\
1923 \\
1934 \\
1940 \\
1942 \\
1944 \\
1944 \\
1946 \\
1948 \\
1949 \\
1950 \\
1951 \\
1953\end{array}$ & $\begin{array}{l}22.8 \\
36.4 \\
30.3 \\
32.3 \\
44.0 \\
31.8 \\
21.3 \\
31.0 \\
32.7 \\
35.3 \\
22.0 \\
36.0 \\
34.7\end{array}$ & $\begin{array}{l}29.9 \\
29.7 \\
29.3 \\
28.8 \\
29.2 \\
26.7 \\
26.7 \\
29.8 \\
28.1 \\
30.7 \\
25.7 \\
28.2 \\
28.2 \\
\end{array}$ & $\begin{array}{l}32.8 \\
34.4 \\
29.3 \\
38.7 \\
49.3 \\
41.7 \\
\text { NK } \\
31.9 \\
33.9 \\
35.3 \\
22.9 \\
37.5 \\
31.9 \\
\end{array}$ & $\begin{array}{l}31.6 \\
31.4 \\
31.0 \\
30.5 \\
30.9 \\
28.4 \\
28.4 \\
31.5 \\
29.8 \\
32.3 \\
27.4 \\
29.9 \\
29.9\end{array}$ & $\begin{array}{r}10.0 \\
-2.0 \\
-1.0 \\
6.4 \\
5.3 \\
9.9 \\
0.9 \\
1.2 \\
0.0 \\
0.9 \\
1.5 \\
-2.8\end{array}$ & $\begin{array}{l}3.1 \\
1.6 \\
1.6 \\
1.6 \\
1.1 \\
1.6 \\
1.6 \\
1.6 \\
1.6 \\
3.1 \\
1.6 \\
1.6\end{array}$ \\
\hline Mean (years) & 31.6 & 28.5 & 35.0 & 30.2 & 2.5 & 1.8 \\
\hline SE & 1.72 & & 1.81 & & 0.80 & \\
\hline$p^{* *}$ & $<0.1$ & & $<0.05$ & & & \\
\hline
\end{tabular}

* From the Registrar General's Tables and adjusted for parity except for the years 1921, 1923,1934 (see text).

+ Based on the expected maternal age plus the appropriate age difference given in Table II.

$¥$ Based on the observed maternal age and the figures given in Table II.

* * Probability (on $t$ test) that the observed data could arise from the same parental age distribution as that of the general population. 
In conclusion, the observed parental ages of patients in this study have been compared to (1) population maternal age data (after 1938 this has been adjusted for parity); (2) husband-wife or father-mother age differences in the population; and (3) paternal ages estimated from (1) and (2). Significance of the comparisons has been estimated using the $t$ test and the standard error of the mean for the observed data.

\section{Clinical features of index patients}

All but three of the index patients fell into two main clinical groups. There was a group of 17 patients (hereafter called group A) where onset of illness was in childhood, where dystonia of a limb was the first symptom, and where there was eventual bilateral involvement. These 17 patients were clinically similar to each other and none had distinctive features. There were six males and 11 females and the present ages of the patients ranged from 20 to 56 years. Two patients were Ashkenazi Jews. The clinical findings of patients in this group are given individually in Appendix 1 (p. 18) and are summarized in Table IV. The mean age of onset was 8.8 years, and onset was with dystonia of one or both legs in 13 patients, and with dystonia of an arm in four patients. All but one (case 15) ultimately developed dystonia of four limbs, and all but two ultimately had dystonia of neck or trunk. At present seven of the 17 patients are severely disabled.

There was a second group of 12 patients (hereafter called group B) consisting of three males and nine females whose illness started in adult life with torticollis, or with dystonia of an upper limb. Only four patients in this group developed bilateral signs and none had dystonia of a leg. Of the 12 patients, 11 are relatively mildly affected. Some of the patients had additional features (such as coarse tremor or chorea) and these are indicated in Appendix 1. Two patients spontaneously improved and one of these made a complete recovery.

There were three patients who did not fall into one of these two clinical groups. Case 30 had onset in childhood, after an attack of measles, and after 25 years of illness his signs remain unilateral. Case 31 had onset in childhood with grimacing and dysar-

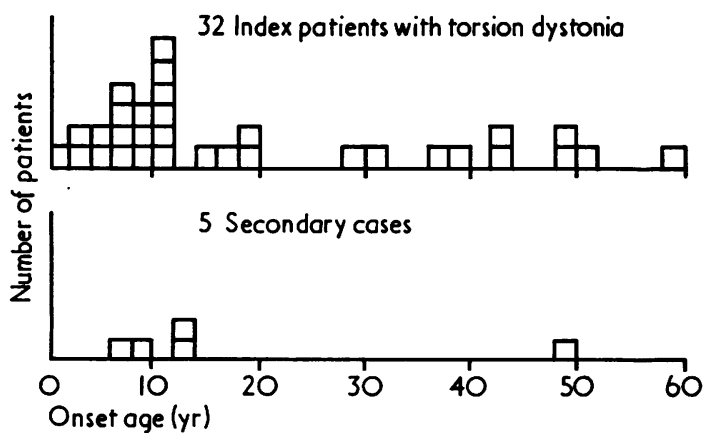

Fig. 1. Distributions of ages on onset of index patients with torsion dystonia and of their affected relatives.

thria; he subsequently developed schizophrenia. Case 32 had onset in childhood, also after measles, with torticollis.

Figure 1 shows the distribution of ages of onset of the patients. Those patients with onset before 20 years (most of whom comprise group A above) form a relatively compact group, in contradistinction to the remaining 10 patients whose ages of onset are very scattered.

Of the 32 patients, 23 were included in the clinical study of Marsden and Harrison (1974).

\section{Genetic findings}

Families of patients with onset of dystonia in childhood, affecting firstly a limb, and ultimately involving both sides of the body (group A patients). There were 17 patients in this group. No parent was affected; 29 out of the 34 were examined. There were two affected sibs out of 24, the brothers of cases 6 and 10. Case 6 also had an affected second cousin once removed. There was no known consanguinity in this family, but the index patient's parents, and the 'cousin's' parents all come from neighbouring villages in County Durham. Case 13 had an affected first cousin; this family were Ashkenazi Jews. The four secondary cases had similar illnesses to those in the index patients; brief clinical details are added to Appendix 1 . The 18 healthy living sibs were aged 17 to 62 years; three sibs had died in infancy and one at 28 years in an accident.

TABLE IV

CLINICAL FEATURES OF THE TWO MAIN GROUPS OF PATIENTS WITH TORSION DYSTONIA

\begin{tabular}{|c|c|c|c|c|c|c|c|c|}
\hline \multirow{2}{*}{\multicolumn{2}{|c|}{$\begin{array}{l}\text { No. of Patients } \\
(\mathbf{M}: \mathbf{F})\end{array}$}} & \multirow{3}{*}{$\begin{array}{c}\begin{array}{c}\text { Mean Age } \\
\text { of Onset }\end{array} \\
8.8 \text { years }\end{array}$} & \multicolumn{3}{|c|}{ Mode of Onset } & \multirow{3}{*}{$\begin{array}{c}\begin{array}{c}\text { No. with } \\
\text { Bilateral } \\
\text { Signs }\end{array} \\
17\end{array}$} & \multirow{3}{*}{$\begin{array}{c}\begin{array}{c}\text { No. at Work } \\
\text { in } 1973\end{array} \\
10 \\
\end{array}$} & \multirow{3}{*}{$\begin{array}{c}\text { No. Severely } \\
\text { Handicapped }\end{array}$} \\
\hline & & & \multirow{2}{*}{$\begin{array}{c}\text { Leg } \\
13 \\
\end{array}$} & \multirow{2}{*}{$\begin{array}{c}\text { Arm } \\
4 \\
\end{array}$} & \multirow{2}{*}{$\begin{array}{c}\text { Neck or Trunk } \\
0 \\
\end{array}$} & & & \\
\hline Group A & $6: 11$ & & & & & & & \\
\hline Group B & $3: 9$ & 39.5 years & 0 & 6 & 6 & 4 & 11 & 1 \\
\hline
\end{tabular}


There was no known parental consanguinity in any of the 17 families. No patient was a twin. Only one patient had a child, a healthy, one-year-old daughter. The genetic data are given in Appendix 2 (p. 19).

Fitness. The effective fertility of the patients was compared to that of their similarly aged and unaffected sibs. The patients, 17 index patients and four secondary cases, were aged 20 to 56 years with a mean of 31.2 years. Between them they had one child. Their 19 unaffected sibs (excluding those younger than 20) were aged 26 to 62 years, with a mean of 33.4 years. Between them they had 22 children.

Parental age of isolated cases in group $A$. There were 14 isolated cases in this group, but one had no knowledge of either parent's age and another did not know her father's. The ages of the 13 mothers and 12 fathers have been compared to parental ages in the general population for the appropriate years of birth (Table III). The observed mean maternal age at birth of these isolated cases of torsion dystonia was 31.6 years (SEM 1.72), which is higher, but not significantly so, than the expected mean maternal age of 28.5 years. However, the observed mean paternal age was significantly higher than the paternal age expected from the population data: 35.0 years (SEM 1.81 years) compared to 30.2 years $(p<0.05)$. The paternal-maternal age difference is also increased, though not significantly so. The mean paternal-maternal age difference expected from the mother's ages was 1.8 years; but the observed mean difference was 2.5 years.

Families of patients with onset in adult life, presenting with torticollis or dystonia of an upper limb (group B patients). Among the first-degree relatives of the 12 patients in this group there were no known secondary cases. However, information on the families of these older patients was often scanty, as relatives had died or the index patient was no longer in touch with them. Of the 24 parents only eight were personally examined; of the 51 sibs reliable information was only available on 21. Information regarding offspring however was nearly complete: 20 of 24 living offspring were seen; their ages ranged from 53 to 2 years.

There was one confirmed secondary case: the paternal grandmother of case 19 . She had had a coarse tremor for 28 years and latterly had developed spasmodic torticollis. She had no dystonia in the limbs. Her grand-daughter developed spasmodic torticollis at the age of 19 and was found to have dystonia of the right hand and a coarse tremor. The father of the index patient had died of unknown cause at 35 years. He had five living sibs, who were all healthy.

One patient, case 21, was born to first cousin parents. Her illness was unusual in that she made a complete and spontaneous recovery. Her seven sibs, who were all in Ireland, were said to be normal.

Families of patients not falling into the above two categories (patients 30-32). There were no secondary cases in these families. There were six healthy parents, five healthy sibs, and one healthy four-year-old child. The complete genetic data on these and the families in groups $A$ and $B$ are given in Appendix 2.

\section{Discussion}

Patients in group A. A group of 17 patients who appeared clinically similar to one another could be separated from the clinically heterogenous series. This group had onset before 20 years, with dystonia of a limb, generally a leg. Bilateral involvement always followed. They would fit Herz's category of juvenile torsion dystonia, exemplified by his cases $1-7$, if his upper age limit is extended to 20 years (Herz, 1944). Four of the five secondary cases in the whole series belonged to families in this group; two were sibs and two were cousins, the latter in families where consanguinity was suspected but not confirmed. None of the 34 parents was affected. It is likely that the three families containing the four secondary cases demonstrated autosomal recessive inheritance of torsion dystonia. One of these families was Jewish; two were not. In all, two sibs were affected out of 24, or two out of 21 if the three sibs who died young are excluded. The unaffected sibs are 17 years or older and it is unlikely that any will develop torsion dystonia in the future. This incidence is too low for the 1 in 4 incidence which would be seen if all cases were explained by autosomal recessive inheritance. Let us suppose that half the patients in group $A$ had autosomal recessive torsion dystonia, with a 1 in 4 risk for sibs to be affected, and the other half had a form of torsion dystonia without a risk of recurrence. In such a situation out of 21 who survived to 17 years, one would expect 2.62 sibs $\left(21 \times \frac{1}{2} \times \frac{1}{4}\right)$ to be affected. Let us now suppose that a third of patients in group A had recessive torsion dystonia, and that for two thirds there was no risk for sibs. Then one would expect 1.75 sibs $\left(21 \times \frac{1}{3} \times \frac{1}{4}\right)$ to be affected. In fact two sibs were affected out of 21 . The numbers are small but it is probably reasonable to say that a third to a half of cases of juvenile torsion dystonia had the autosomal recessive form. In this series this would be six to eight cases (the three familial ones, plus 
three to five chance isolated cases), leaving nine to 11 index patients, clinically similar to the remainder, whose disease could not be explained by autosomal recessive inheritance.

We suggest that these patients, a half to two thirds of all cases of juvenile torsion dystonia, are examples of new dominant mutations. In favour of this hypothesis is the probable paternal age effect. For the isolated cases of torsion dystonia in group $\mathbf{A}$ show a significant increase in mean paternal age, 35.0 years compared to an expected mean of $\mathbf{3 0 . 2}$ years $(p<0.05)$. The paternal-maternal age difference is also increased (2.5 years compared to 1.8 years) but not significantly so. This increase in paternal age has been observed even though some of the isolated cases must be examples of chanceisolated recessive cases where no paternal age effect is likely. We consider the increase in paternal age to indicate that some of the isolated cases of juvenile torsion dystonia are dominant mutations. A paternal age effect has been observed before for dominant mutations for skeletal disorders (Penrose, 1955; Blank, 1959/1960; McKusick, 1972), but this is the first time one has been demonstrated for mutation in a neurological disorder.

The reduced fertility of patients with juvenile torsion dystonia may explain why no example of parent-child transmission has been observed in this group. The patients in this group have only one child between them, and compared to their unaffected sibs, their fertility is reduced to $1 / 20$. Thus if there were an autosomal dominant form of juvenile torsion dystonia, only about 1 in 20 of such dominant cases would have an affected parent, the remainder being examples of new mutations. It is therefore not surprising in a small series to find no example of an affected parent. Proof that some of these isolated cases are dominant mutations will come if one or more patients has an affected child; the only child so far born is too young to be assessed.

Two patients in this group of 17 were Ashkenazi Jews. As the incidence of Ashkenazi Jews in South-East England is about 2-3\% (Prais and Schmool, 1968), this is likely to represent an unusually high incidence of torsion dystonia in Jews and to support the observations of Eldridge (1970) in the United States.

Remaining patients. The remaining 15 patients were, in contrast, clinically heterogenous. There appeared to be a benign dominant form of torsion dystonia, as shown by patient 19 and her family. This was associated with a coarse tremor and may be the same as that described by Johnson et al (1962) and by Yanagisawa et al (1972). Cases
18 and 20 also had a tremor, but they did not have an affected relative. It is possible that one or two of the patients whose parents or sibs could not be examined might also be examples of a benign dominant form, but as no child out of 24 was affected, it is unlikely that any considerable proportion is dominant. The fitness of patients with adult-onset torsion dystonia was not reduced when compared to that of their sibs. One adult-onset patient (case 21) was born to consanguineous parents, but as she spontaneously recovered from her illness, and as none of her seven sibs was affected, we think recessive inheritance in her case is unlikely. For most adult-onset patients we consider that environmental, non-genetic factors may operate, particularly in eight with unilateral involvement, and in two who spontaneously improved. However, although many non-genetic causes of symptomatic torsion dystonia have been described (Zeman and Whitlock, 1968), none could be identified with certainty in cases 18 and $20-32$.

Our series is too small to determine whether or not benign adult-onset torsion dystonia is genetically distinct from the severe dominant childhood form. Both clinical types can occur in the same family (Eldridge et al, 1971) and it may be that late onset, with torticollis, is a milder and more unusual manifestation of that gene which causes severe bilateral involvement when onset is in childhood.

Genetic counselling. The number of families in this study is small. However it is likely that when torsion dystonia develops in childhood, with dystonia of a limb and with eventual bilateral involvement, that about a third to a half of such cases will be autosomal recessive, and about a half to two thirds autosomal dominant, without clinical distinction. (For Ashkenazi Jews the recessive form may be commoner than the dominant form: Eldridge, 1970.) In advising parents of an isolated case, the risk of their having a second affected child may be about 1 in 10 or 1 in 12 (probably higher if Jewish). In advising isolated patients with childhood onset torsion dystonia, the risk of their having an affected child may be as high as 1 in 3 (probably less for Jewish patients). This latter risk is based on theoretical grounds, and not on observation.

It is likely that the majority of patients with onset in adult life, or with unilateral involvement, have a non-genetic variety of torsion dystonia. A few, however, are examples of a dominant form often associated with a tremor. In spite of one instance in this series of consanguinity, we do not consider that there is an adult-onset recessive form of torsion dystonia. 
We thank the consultants of the National Hospitals, and of The Hospital for Sick Children for allowing us to study patients under thelr care. We thank Dr J. M. Roderick for allowing us to include case 16 . We are grateful to Professor R. W. Gilliatt for his help during this study, and to Dr C. O. Carter for his advice in the preparation of this paper.

\section{REFERENCES}

Bundey, S. and Evans, K. A. (1969). Tuberous sclerosis: a genetic study. Fournal of Neurology, Neurosurgery and Psychiatry, 32, 591-603.

Blank, C. E. (1959/1960). Apert's syndrome. A type of acrocephalosyndactyly -observations on a British series of thirty-nine cases. Annals of Human Genetics, 24, 151-164.

Eldridge, R. (1970). The torsion dystonias. Neurology, 20, No. 11, pt. 2, 1-78.

Eldridge, R., Edgar, A., and Cooper, I. S. (1971). Genetics, geography and intelligence in the torsion dystonias. Birth Defects: Original Article Series. 7, pt. 6,167-177. National FoundationMarch of Dimes, New York.

Herz, E. (1944). Dystonia I and II. Archives of Neurology and Psychiatry, 51, 305-355.

Johnson, W., Schwartz, G., and Barbeau, A. (1962). Studies on dystonia musculorum deformans. Archives of Neorology, 7, 301313.
Larsson, T. and Sjögren, T. (1966). Dystonia musculorum deformans. Acta Neurologica Scandinavica, 42, Suppl. 17.

McKusick, V. A. (1972). Heritable Disorders of Connective Tissue, 4th edition. C. V. Mosby, St. Louis.

Marsden, C. D. and Harrison, M. J. G. (1974). Idopathic torsion dystonia. Brain. (In press.)

Penrose, L. S. (1955). Parental age and mutation. Lancet, 2, 312313.

Prais, S. J. and Schmool, M. (1968). The size and structure of the Anglo-Jewish population 1960-1965. Fewish fournal of Sociology, 10, 5-34.

Yanagisawa, N., Goto, A., and Narabayashi, H. (1972). Familial dystonia musculorum deformans and tremor. Fournal of the Neurological Sciences, 16, 125-136.

Zeman, W. and Dyken, P. (1967). Dystonia musculorum deformans. Psychiatria, Neurologia, Neurochirugia, 70, 77-121.

Zeman, W. and Dyken, P. (1968). Dystonia musculorum deformans. In Handbook of Clinical Neurology, vol. 6, ed. by P. J. Vinken and G. W. Bruyn, pp. 517-543. North Holland, Amsterdam.

Zeman, W., Kaelbling, R., Pasamanick, B., and Jenkins, J. T. (1959) Idiopathic dystonia musculorum deformans. I. The hereditary pattern. American fournal of Human Genetics, 11, 188-202.

Zeman, W. and Whitlock, C. C. (1968). Symptomatic dystonias. In Handbook of Clinical Neurology, vol. 6, ed. by P. J. Vinken and G. W. Bruyn, pp. 544-566. North Holland, Amsterdam.

Appendix 1

CLINICAL FEATURES IN PATIENTS WITH TORSION DYSTONIA

\begin{tabular}{|c|c|c|c|c|c|c|c|c|c|c|c|c|c|c|}
\hline \multirow{2}{*}{ 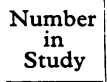 } & \multirow{2}{*}{$\begin{array}{l}\text { Hospital } \\
\text { Number* }\end{array}$} & \multirow{2}{*}{ Sex } & \multirow{2}{*}{ Age } & \multirow{2}{*}{$\begin{array}{c}\text { Onset } \\
\text { Age (years) }\end{array}$} & \multirow{2}{*}{$\begin{array}{l}\text { Mode } \\
\text { of } \\
\text { Onset }\end{array}$} & \multicolumn{7}{|c|}{ Involvement at its Worst $†$} & \multirow{2}{*}{ 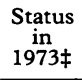 } & \multirow{2}{*}{ Other Features } \\
\hline & & & & & & $\mathbf{S}$ & $\mathbf{N}$ & $\mathrm{T}$ & OA & BA & OL & BL & & \\
\hline \multicolumn{2}{|c|}{ 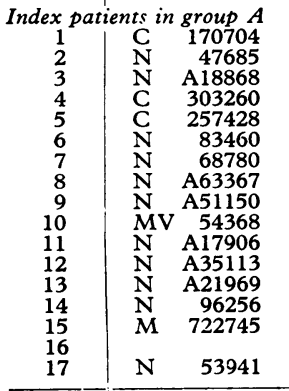 } & $\begin{array}{l}F \\
M \\
M \\
F \\
M \\
F \\
M \\
F \\
F \\
F \\
F \\
F \\
M \\
F \\
F \\
M \\
F\end{array}$ & $\begin{array}{l}24 \\
20 \\
50 \\
26 \\
27 \\
26 \\
25 \\
29 \\
29 \\
56 \\
22 \\
52 \\
20 \\
31 \\
23 \\
39 \\
33\end{array}$ & $\begin{array}{c}1-2 \\
3 \\
3 \\
5 \\
7 \\
7 \\
8 \\
8 \\
8-9 \\
10 \\
10-11 \\
10-11 \\
10-11 \\
11 \\
10-12 \\
16 \\
19\end{array}$ & $\begin{array}{l}\text { OL } \\
\text { BL } \\
\text { BL } \\
\text { OL } \\
\text { OL } \\
\text { OL } \\
\text { OL } \\
\text { OL } \\
\text { OA } \\
\text { OL } \\
\text { OL } \\
\text { OL } \\
\text { OL } \\
\text { OA } \\
\text { OA } \\
\text { OA } \\
\text { OL }\end{array}$ & $\begin{array}{l}+ \\
+ \\
0 \\
+ \\
0 \\
0 \\
+ \\
+ \\
+ \\
+ \\
0 \\
+ \\
+ \\
+ \\
0 \\
+ \\
+\end{array}$ & $\begin{array}{l}0 \\
+ \\
+ \\
+ \\
+ \\
0 \\
+ \\
+ \\
+ \\
0 \\
+ \\
+ \\
+ \\
+ \\
0 \\
+ \\
+\end{array}$ & $\begin{array}{l}0 \\
+ \\
+ \\
+ \\
+ \\
0 \\
+ \\
0 \\
+ \\
+ \\
+ \\
+ \\
+ \\
+ \\
0 \\
+ \\
+\end{array}$ & & $\begin{array}{l}+ \\
+ \\
+ \\
+ \\
+ \\
+ \\
+ \\
+ \\
+ \\
+ \\
+ \\
+ \\
+ \\
+ \\
+ \\
+ \\
+\end{array}$ & $\mathbf{O}$ & $\begin{array}{l}+ \\
+ \\
+ \\
+ \\
+ \\
+ \\
+ \\
+ \\
+ \\
+ \\
+ \\
+ \\
+ \\
+ \\
0 \\
+ \\
+\end{array}$ & $\begin{array}{l}1 \\
4 \\
3 \\
5 \\
3 \\
2 \\
4 \\
3 \\
3 \\
4 \\
4 \\
5 \\
3 \\
5 \\
2 \\
2 \\
3\end{array}$ & \\
\hline \multicolumn{2}{|c|}{ 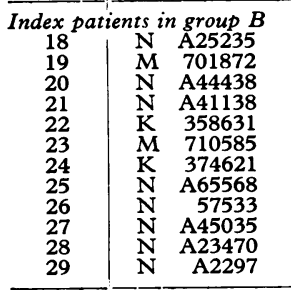 } & $\begin{array}{l}\text { F } \\
F \\
F \\
F \\
M \\
\text { F } \\
\text { F } \\
\text { M } \\
\text { M } \\
\text { F } \\
\text { F } \\
\text { F }\end{array}$ & $\begin{array}{l}31 \\
23 \\
47 \\
37 \\
46 \\
44 \\
46 \\
46 \\
75 \\
57 \\
62 \\
71\end{array}$ & $\begin{array}{l}18 \\
19 \\
29 \\
31 \\
38 \\
40 \\
44 \\
44 \\
50 \\
50 \\
52 \\
59\end{array}$ & $\begin{array}{l}\mathbf{N} \\
\mathbf{N} \\
\text { OA } \\
\text { OA } \\
\text { OA } \\
\mathbf{T} \\
\mathbf{N} \\
\mathbf{N} \\
\text { OA } \\
\text { OA } \\
\text { OA } \\
\mathbf{N}\end{array}$ & $\begin{array}{l}\mathbf{O} \\
\mathbf{O} \\
\mathbf{O} \\
\mathrm{O} \\
\mathbf{O} \\
\mathrm{O} \\
\mathrm{O} \\
+ \\
+ \\
+ \\
\mathbf{O} \\
\mathrm{O}\end{array}$ & $\begin{array}{l}+ \\
+ \\
+ \\
+ \\
+ \\
0 \\
+ \\
+ \\
+ \\
+ \\
0 \\
+\end{array}$ & $\begin{array}{l}\text { O } \\
\text { O } \\
\text { O } \\
\text { O } \\
+ \\
+ \\
\text { O } \\
\text { O } \\
\text { O } \\
\text { O } \\
\text { O } \\
+\end{array}$ & $\begin{array}{l}+ \\
+ \\
0 \\
+ \\
+ \\
+ \\
+ \\
+\end{array}$ & $\begin{array}{l}+ \\
\text { O } \\
+ \\
\text { O } \\
+ \\
\text { O } \\
\text { O } \\
\text { O } \\
+ \\
\text { O } \\
\text { O } \\
\text { O }\end{array}$ & $\begin{array}{l}\mathrm{O} \\
\mathrm{O} \\
\mathrm{O} \\
\mathrm{O} \\
\mathrm{O} \\
\mathrm{O} \\
\mathrm{O} \\
\mathrm{O} \\
\mathrm{O} \\
\mathrm{O} \\
\mathrm{O} \\
\mathrm{O}\end{array}$ & $\begin{array}{l}\mathrm{O} \\
\mathrm{O} \\
\mathrm{O} \\
\mathrm{O} \\
\mathrm{O} \\
\mathrm{O} \\
\mathrm{O} \\
\mathrm{O} \\
\mathrm{O} \\
\mathrm{O} \\
\mathrm{O} \\
\mathrm{O}\end{array}$ & $\begin{array}{l}2 \\
2 \\
2 \\
1 \\
3 \\
3 \\
2 \\
4 \\
3 \\
2 \\
1 \\
1 \\
2\end{array}$ & $\begin{array}{l}\text { Tremor } \\
\text { Coarse tremor } \\
\text { Coarse tremor } \\
\text { Spontaneous recovery } \\
\text { Trunk only affected } \\
\text { Cervical spondylosis } \\
\text { Choreiform movements } \\
\text { Spontaneously improved }\end{array}$ \\
\hline \multicolumn{2}{|c|}{\begin{tabular}{c|cc}
\multicolumn{3}{l}{ Index patients, unclassified } \\
30 & N & A6033 \\
31 & M 595078 \\
32 & M 708372 \\
\end{tabular}} & $\begin{array}{l}M \\
M \\
M\end{array}$ & $\begin{array}{l}31 \\
23 \\
28\end{array}$ & $\begin{array}{r}6 \\
10 \\
11\end{array}$ & $\underset{\mathrm{N}}{\mathrm{OA}}$ & $\begin{array}{l}\text { O } \\
+ \\
+\end{array}$ & $\begin{array}{l}\text { O } \\
+ \\
+\end{array}$ & $\begin{array}{l}\text { O } \\
+ \\
+\end{array}$ & + & $\begin{array}{l}\text { O } \\
+ \\
+\end{array}$ & + & $\begin{array}{l}\text { O } \\
+ \\
+\end{array}$ & $\begin{array}{l}1 \\
4 \\
5\end{array}$ & $\begin{array}{l}\text { Onset followed measles } \\
\text { Schizophrenia } \\
\text { Onset followed measles }\end{array}$ \\
\hline \multicolumn{2}{|c|}{$\begin{array}{l}\text { Secondary Cases } \\
\text { Brother of case } 6 \\
\text { 'Cousin' of case } 6 \\
\text { Brother of case } 10 \\
\text { First cousin of case } 13 \\
\text { Father's mother of case } 19\end{array}$} & $\begin{array}{l}M \\
F \\
M \\
M \\
F\end{array}$ & $\begin{array}{l}24 \\
26 \\
49 \\
24 \\
78\end{array}$ & $\begin{array}{r}13 \\
8 \\
14 \\
10 \\
50\end{array}$ & $\begin{array}{l}\mathrm{OL} \\
\mathrm{OL} \\
\mathrm{OA} \\
\mathrm{OL} \\
\mathrm{N}\end{array}$ & $\begin{array}{l}\text { O } \\
+ \\
\stackrel{+}{+} \\
\stackrel{+}{O}\end{array}$ & $\begin{array}{l}\mathrm{O} \\
+ \\
\dot{O} \\
\mathrm{O} \\
+\end{array}$ & $\begin{array}{l}\mathbf{O} \\
+ \\
+ \\
+ \\
+\end{array}$ & $\mathrm{O}$ & $\begin{array}{l}+ \\
+ \\
+ \\
+ \\
+\end{array}$ & $\mathrm{O}$ & $\begin{array}{l}+ \\
+ \\
+ \\
+ \\
+\end{array}$ & $\begin{array}{l}2 \\
5 \\
3 \\
2 \\
2\end{array}$ & $\begin{array}{l}\text { Died in } 1974 \\
\text { Coarse tremor }\end{array}$ \\
\hline
\end{tabular}

* $\mathrm{N}=$ National Hospital, Queens Square; $\mathrm{MV}=$ National Hospital, Maida Vale; $\mathrm{C}=$ The Hospital for Sick Children; $\mathrm{M}=\mathrm{Maudsley}$ Hospital; $\mathrm{K}=$ Kings College Hospital.

+ Dystonia of speech (S), neck (N), trunk (T), one arm (OA), both arms (BA), one leg (OL), both legs (BL).

$¥ 1$ = leading normal life, no symptoms; $2=$ mild disability, continues full-time work; $3=$ moderate disability, works with difficulty; $4=$ severely disabled, not at work, independent at home; $5=$ wholly dependent upon others. 
Appendix 2

GENETIC DATA IN 32 FAMILIES WITH TORSION DYSTONIA (in order of family size)

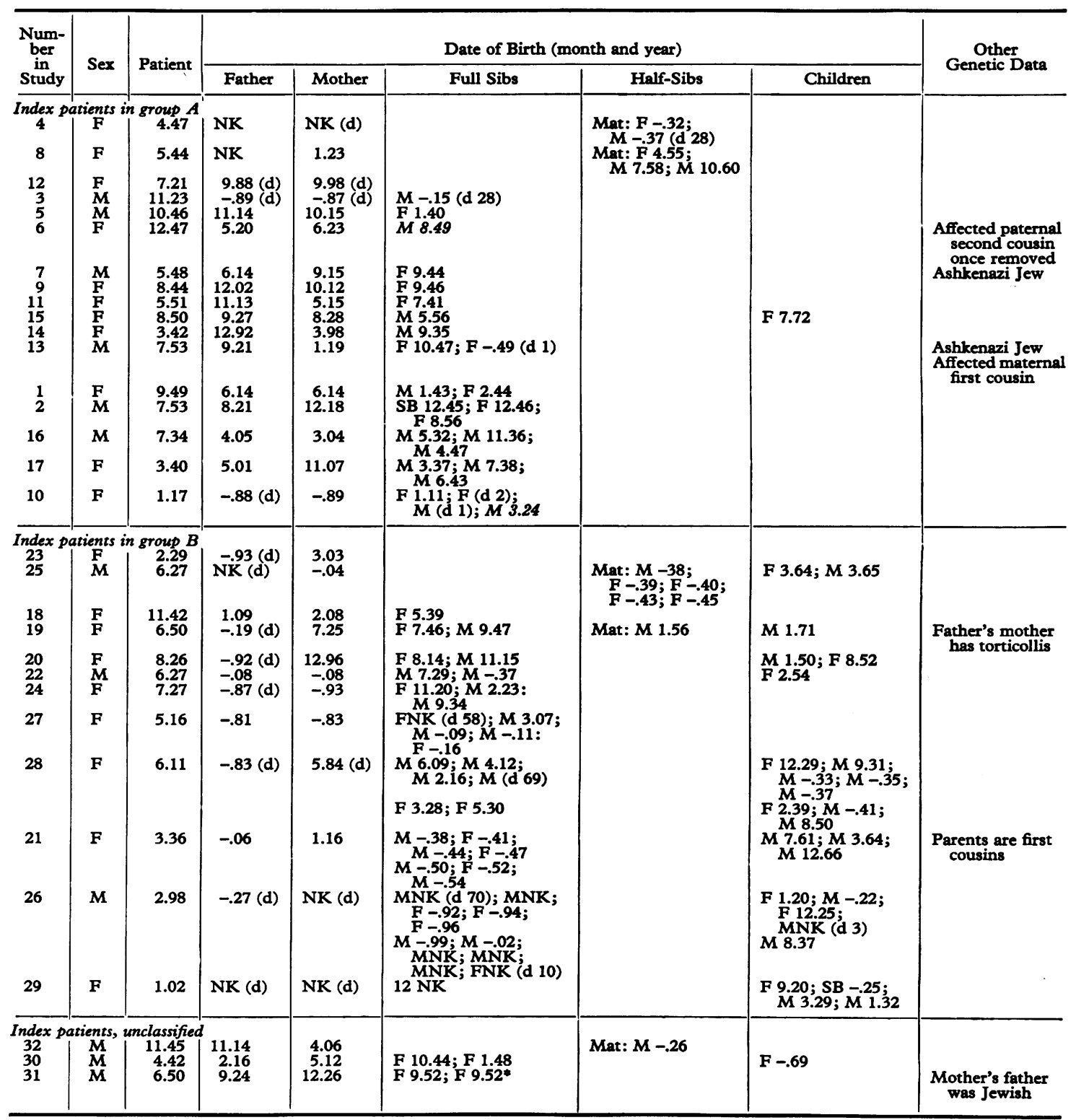

$M=$ male; $F=$ female; $d=$ dead, with age at death if known; $N K=$ not known; $S B=$ stillbirth; affected relatives are given in italics.

- Monozygotic twins. 